\title{
Groundwater Level Effect on Redox Potential, on Cadmium Uptake and Yield of Soybean
}

\author{
Md. Zahidul Haque1, Choichi Sasaki², Nobuhiko Matsuyama², Takeyuki Annaka3 \\ Chihiro Kato ${ }^{2}$ \\ ${ }^{1}$ United Graduate School of Agricultural Sciences (UGAS), Iwate University, Morioka, Japan \\ ${ }^{2}$ Faculty of Agriculture and Life Science, Hirosaki University, Hirosaki, Japan \\ ${ }^{3}$ Faculty of Agriculture, Yamagata University, Tsuruoka, Japan \\ Email: mzhaque81@gmail.com
}

Received 21 July 2014; revised 22 August 2014; accepted 6 September 2014

Copyright (C) 2014 by authors and Scientific Research Publishing Inc.

This work is licensed under the Creative Commons Attribution International License (CC BY). http://creativecommons.org/licenses/by/4.0/

(c) (i) Open Access

\begin{abstract}
In this greenhouse experiment, we investigated the effects of two constant groundwater levels: 10 cm groundwater level (GW-10) and $40 \mathrm{~cm}$ groundwater level (GW-40) and one change groundwater level, which was $40-10-40 \mathrm{~cm}(\mathrm{GW}-40-10-40)$ on Cadmium (Cd) uptake and seed yield of Soybean plant in Cd contaminated soils $\left(1.57 \mathrm{mg} \cdot \mathrm{kg}^{-1}\right)$. The experimental soil layer was made with gravel layer $(14 \mathrm{~cm})$, non-polluted soil $(15 \mathrm{~cm})$ and polluted soil $(25 \mathrm{~cm})$. The redox potential of every soil layer was measured from sowing to harvesting. The soil layer $(10-40 \mathrm{~cm})$ of $\mathrm{GW}-10$ was always in reduction condition and that of $\mathrm{GW}-40$ was always in oxidation condition. First 50 days of GW 40-10-40 were in oxidation and next 50 days in reduction and final 20 days again returned in oxidation condition. Soybean seed Cd concentration was significantly highest in GW-40-10-40 (1.16 $\left.\pm 0.13 \mathrm{mg} \cdot \mathrm{kg}^{-1}\right)$ and lowest in GW-40 $\left(0.81 \pm 0.12 \mathrm{mg} \cdot \mathrm{kg}^{-1}\right)$. Cd concentration of stem was found significantly higher in GW-40 $\left(1.7 \pm 0.2 \mathrm{mg} \cdot \mathrm{kg}^{-1}\right)$ than $\mathrm{GW}-10\left(0.91 \pm 0.08 \mathrm{mg} \cdot \mathrm{kg}^{-1}\right)$ and $\mathrm{GW}-40-10-40\left(1.28 \pm 0.13 \mathrm{mg} \cdot \mathrm{kg}^{-1}\right)$. There was no significant difference in root Cd concentration among these 3 treatments. Main stem height of soybean plant and 100 seed weight of GW-40 were significantly higher than those of $\mathrm{GW}-10$. The result revealed that, soil redox condition is an important factor for Cd uptake in soybean plant and seed yield of soybean. This study will help to manage the farming process more appropriately with the aim of minimizing uptake of Cd and other toxic metals in grain crops.
\end{abstract}

\section{Keywords}

Groundwater Level, Redox Potential (Eh), Cadmium Uptake, Soybean Seed Yield 


\section{Introduction}

Mining, manufacturing and the use of synthetic products (e.g. pesticides, paints, batteries, industrial waste, and land application of industrial or domestic sludge) can result in toxic metal contamination of urban and agricultural soils. These metals also occur naturally, but rarely at toxic levels [1]. However, when the amounts exceed a certain level due to pollutants brought from outside, soil contamination occurs and agricultural products become contaminated. Excess of this metal accumulation in soils is toxic to humans and other animals. Exposure to toxic metals is normally chronic (exposure over a long period of time), due to food chain transfer. It poses a great threat to the environment and human health worldwide due to the persistent nature and toxicity and their accumulation in the food chain [2]. Among toxic metals, Cadmium (Cd) has been recognized as one of the most inimical metals in Japan for Itai-itai disease in Toyama prefecture [3]. Cd occurs naturally in the environment in its inorganic form as a result of volcanic emissions and weathering of rocks. Foodstuffs are the main source of Cd exposure for the non-smoking general population. Cd absorption after dietary exposure in humans is relatively low (3\% - 5\%) but it is efficiently retained in the kidney and liver in the human body, with a very long biological half-life ranging from 10 to 30 years. Cd can also cause bone demineralization, either through direct bone damage or through indirectly as a result of renal dysfunction.

Some methods have been proposed to minimize absorption of Cd by plants from soil, e.g.: 1) soil dressing; 2) chemical cleaning of soil; 3) phytoremediation and 4) use of different varieties and rootstock. However, most of these methods are very costly and time-consuming for effective minimization and have some residual effects also. The redox condition of soil root zone controlled by groundwater level management can be another effective method. Soil is a dynamic and complex system, and any changes in intrinsic physico-chemical properties of toxic metal would surely change the fate of heavy metals in a soil system. Theoretical prediction of toxic metal equilibrium as affected by $\mathrm{pH}$ and redox potential has been studied [4]. The influence of redox potential on arsenic speciation and solubility in a contaminated soil was also reported [5]. Furthermore, the environmental and economic benefits of groundwater level management through reduced pollution and increased yields have been documented [6] [7].

Soybean is a globally important crop providing oil and protein and fastest expanding crops in terms of both calorie and protein intake. Soybeans are a versatile food and one of the central ingredients of Japanese cuisine. They continue the basis of many distinct Japanese flavors, such as soy sauce, miso and tofu, and are processed into countless culinary products. A large-scale domestic agricultural products survey in Japan showed that, $16.7 \%$ of soybean contains over $0.2 \mathrm{mg} / \mathrm{kg}$ and $49.4 \%$ contains over $0.1 \mathrm{mg} / \mathrm{kg} \mathrm{Cd}$ [8]. However, Codex Alimentarius Commission [9] proposed that the maximum allowable limit of Cd in soybean is $0.2 \mathrm{mg} / \mathrm{kg}$. So, it is essential to minimize the uptake of $\mathrm{Cd}$ from polluted soils and increase the seed yield of soybean. As we mentioned previously, the redox condition of soil layer is important and useful for both avoiding heavy metal uptake and increasing soybean yield. The objective of the study is to find out the relation between groundwater level on redox potential on cadmium uptake and soybean yield. This will help to minimize uptake of toxic metals especially Cd in different grain crops.

\section{Materials and Methods}

\subsection{Soil Properties}

The experiment was conducted in the greenhouse of Hirosaki University located in Aomori prefecture in Japan. In this study, we used two types of soil collected from two different areas. Cd contaminated soil was sampled from Eastern area of Japan of which contains $1.57 \mathrm{mg} \cdot \mathrm{kg}^{-1} \mathrm{Cd}$, and non-contaminated soil was collected from Kanagi farm, Aomori prefecture. Gravel was collected from near the Iwaki Mountain area. The physical and chemical properties of the soil (Table 1) were measured by the standard methods of analysis [10]. Before setting up the apparatus, first, weeds, small stones and plant debris were removed from the collected soil. After cleaning, soil balls were made of $12-15 \mathrm{~cm}$ in diameter and dried. Then the soil balls were broken with hammer and the broken clods were sieved in a $4.75 \mathrm{~mm}$ opening mesh for making sure that the similar size of the clods could be used in the experiment.

\subsection{Experimental Design}

We made three plastic containers $(61 \mathrm{~cm} \times 41 \mathrm{~cm} \times 63 \mathrm{~cm})$ and all of them were filled with gravel (small stone crust; bottom $14 \mathrm{~cm}$ ), non-polluted soil $(15 \mathrm{~cm}$ ) and polluted soil (top $25 \mathrm{~cm}$ ) shown in Figure 1. After filling 
Table 1. Soil physical and chemical properties.

\begin{tabular}{ccccccc}
\hline Sample & Dry bulk density $\left(\mathrm{g} \cdot \mathrm{cm}^{-3}\right)$ & Soil texture & $\mathrm{Cd}\left(\mathrm{mg} \cdot \mathrm{kg}^{-1}\right)$ & $\mathrm{T}-\mathrm{N}(\%)$ & $\mathrm{T}-\mathrm{C}(\%)$ & $\mathrm{C} / \mathrm{N}(\%)$ \\
\hline Cd contaminated soil & 0.89 & SL & 1.57 & 0.23 & 2.96 & 12.15 \\
Non-Cd contaminated soil & 0.80 & SCL & 0.12 & 0.14 & 1.80 & 12.62 \\
Gravel & 1.40 & - & $>0.02$ & 0.00 & 0.35 & 0.00 \\
\hline
\end{tabular}

Note: soil texture is based on the International Soil Society classification. SL: Sandy Loam; SCL: Sandy Clay Loam. Gravel diameter size 2 - 4 mm.

the soils, Eh and temperature sensors were set up every soil layer of the three boxes. Three different groundwater level treatments were conducted for the three containers: 1) $10 \mathrm{~cm}$ (GW-10), 2) $40 \mathrm{~cm}$ (GW-40) and 3) $40 \mathrm{~cm}$ for the first 50 days, $10 \mathrm{~cm}$ for the next 50 days and $40 \mathrm{~cm}$ for the last 20 days (GW-40-10-40) (Figure 2).

\subsection{Cultivation Procedure}

In this study Ryuho variety was grown which was recommended for Akita region. After filling the soils in the containers, groundwater level was set up $10 \mathrm{~cm}$ for all treatments, 12 hours before seeding to moist the soil. At the time of seeding the soil water content was around $0.42 \mathrm{~g} \cdot \mathrm{g}^{-1} .12$ hours after seeding, the groundwater level was set up as per treatment. At $1^{\text {st }}$ June (2013), 5 - 6 soybean seeds were sown about $2-3 \mathrm{~cm}$ depth of soil per pit in every box and after 15 days (complete germination) the healthy two remained and others were uprooted. Groundwater level was maintained by Mariotte bottle arrangement which supplied water through the bottom of the plastic box. Groundwater level was measured every day in groundwater level check pipe (4 numbers in each box). Fertilizers (NPK) were applied as per recommended rate for Rhyho variety. In every 4 days, 2 Liter water was supplied in each box that is equal to rainfall of 4 days in Aomori prefecture. Insecticides were periodically sprayed as well.

\subsection{Measurement Procedure}

Oxidation-reduction potential (ORP) of each soil layer was measured by electrometrically using ORP meter (Central Science Co., Ltd., model UC-203) from vegetative to harvesting period. The plant height, number of branches and Soil Plant Analyzer Development (SPAD) of soybean plants were observed continuously from first trifoliate leaf stage. The latest fully developed trifoliate leaf was used for SPAD measurement. After harvesting the seeds, stems and roots were extracted with sulfuric acid and then Cd concentration of each parts of soybeans were measured with Atomic Absorption Spectrophotometer (Model Z-2000, Hitachi Corporation) as described by the Ministry of Agriculture, Forestry and Fisheries of Japan [11].

\section{Statistical Analysis}

Tukey-Kramer test was performed with 5\% significance level to find out difference among Cd uptake in seed, stem and root of soybean plants.

\section{Results and Discussion}

\subsection{Redox Potential (Eh) of Soil Layers}

Oxidation-Reduction Potential (ORP) condition is known as a redox potential (Eh). The Eh value in soil higher than $300 \mathrm{mV}$ is an indicator of oxidation condition and lower than $300 \mathrm{mV}$ indicates reduction condition [12]. Eh value was measured less than $300 \mathrm{mV}$ in below $10 \mathrm{~cm}$ (from soil surface) in GW-10 treatment for saturated condition by high groundwater level (Figure 3). Only Eh values of $5 \mathrm{~cm}$ and $7.5 \mathrm{~cm}$ soil depth were higher than $300 \mathrm{mV}$ that means it was in oxidation condition. So, we can say that in GW-10 treatment, reduction condition was occurred in soil layer below $10 \mathrm{~cm}$ from the soil surface. In case of GW-40 treatment, Eh value was measured over $300 \mathrm{mV}$ (about $700 \mathrm{mV}$ ) for all layer of soil except $40 \mathrm{~cm}$ depth Eh value (Figure 4). It represents that oxidation condition occurred from the surface to $40 \mathrm{~cm}$ depth in GW-40 treatment. And in GW-40-10-40, first 50 days Eh value of soil $(0-40 \mathrm{~cm}$ ) layer was measured about $600 \mathrm{mV}$, next 50 days below $300 \mathrm{mV}$ and last 20 days Eh value was increasing towards over $300 \mathrm{mV}$ (Figure 5). It showed that vegetative period (first 50 days) it was in oxidation condition and reproductive period (next 50 days) was in reduction condition and last 20 days it was again in oxidation condition. 


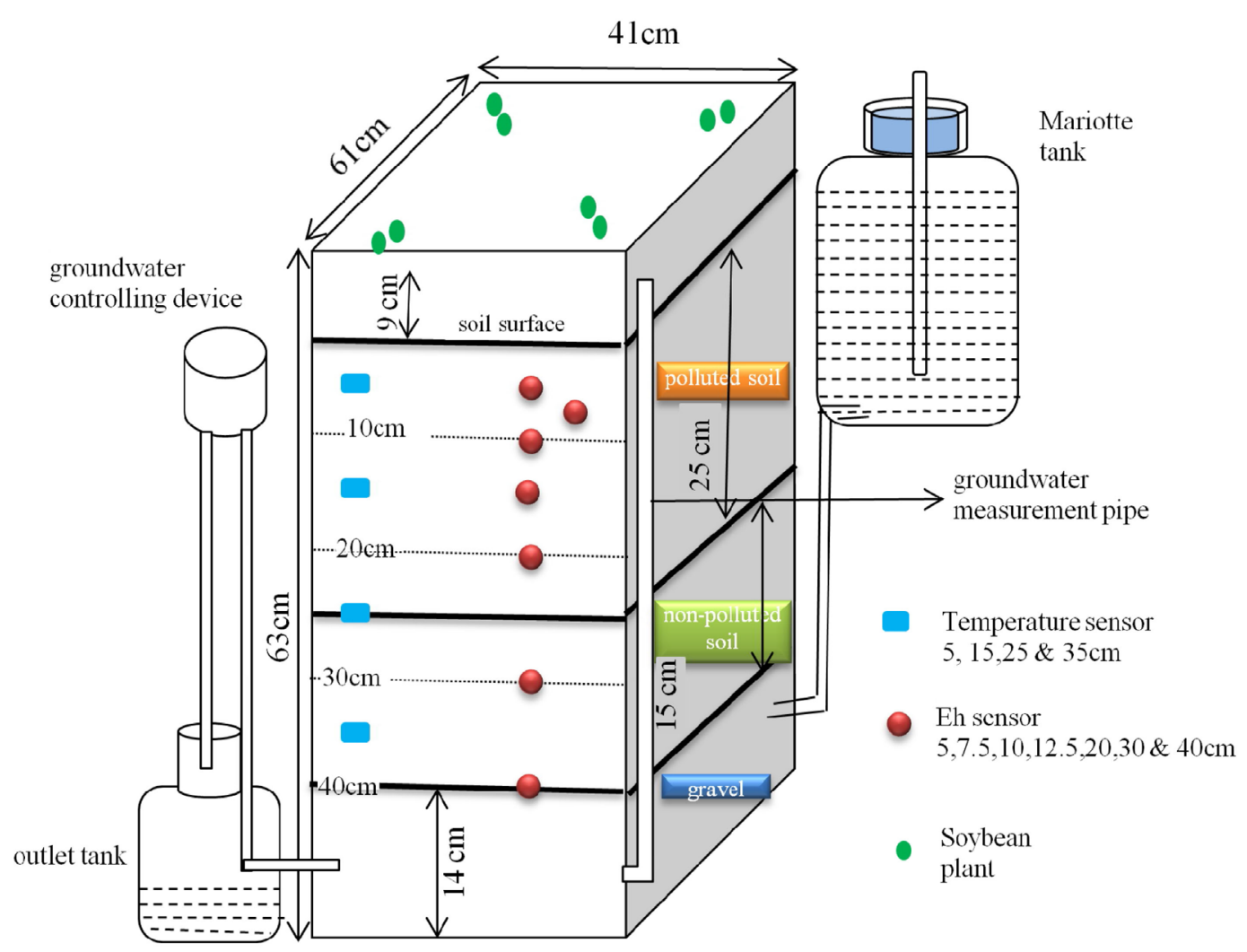

Figure 1. Layout of the plastic container used in the experiment.

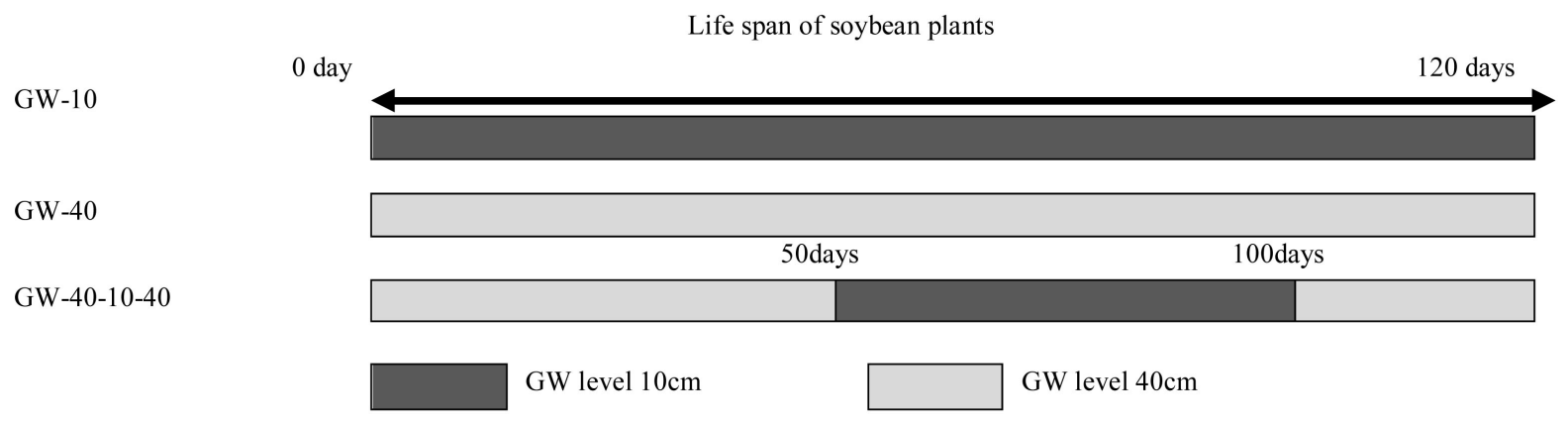

Figure 2. Outline of groundwater level treatments.

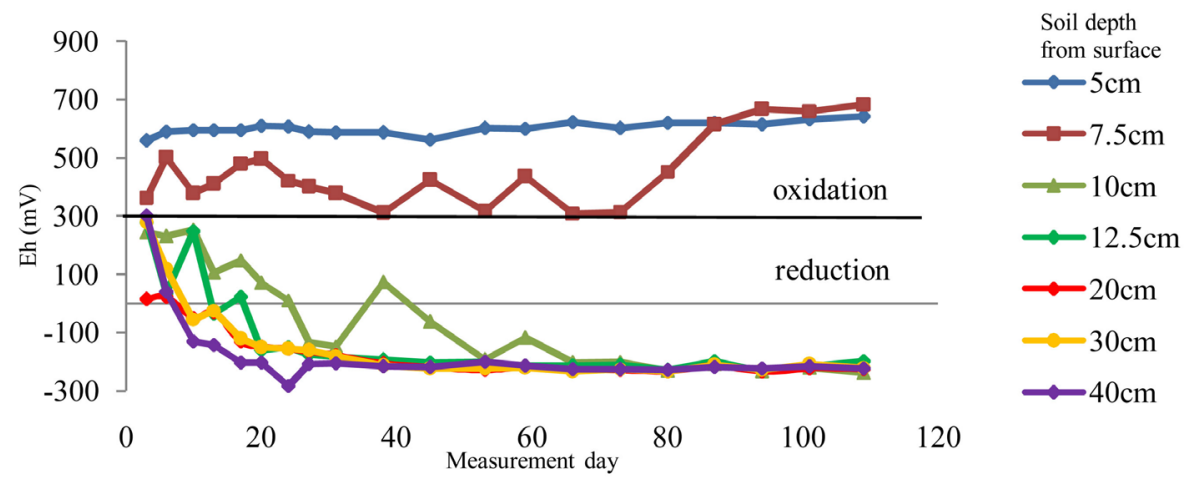

Figure 3. Eh value of GW-10 treatment. 


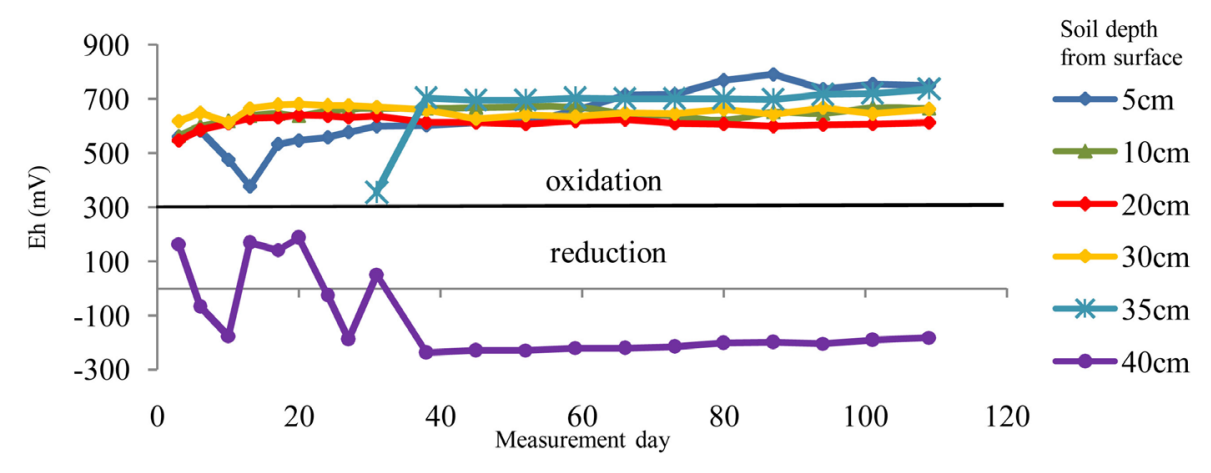

Figure 4. Eh value of GW-40 treatment.

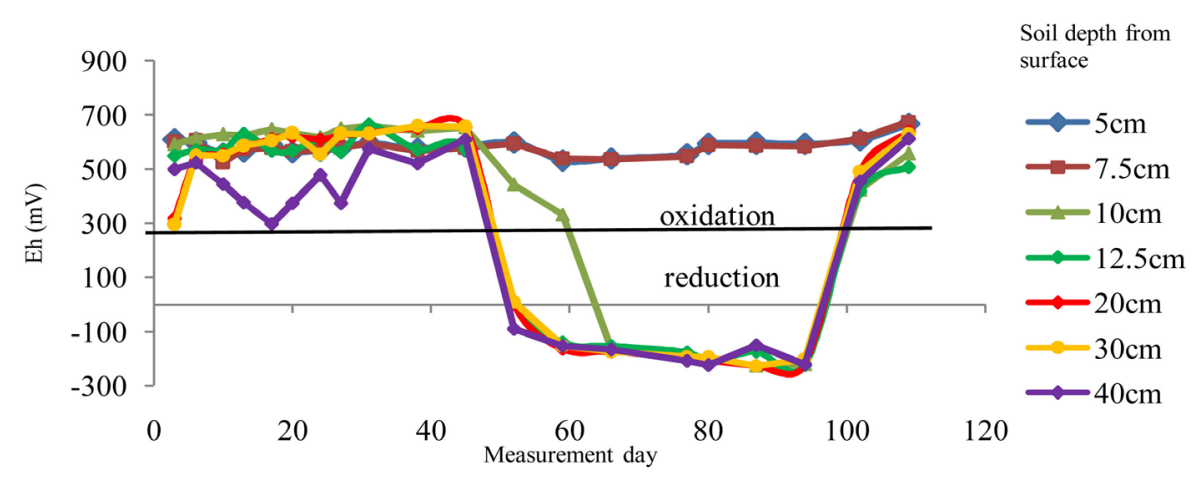

Figure 5. Eh value of GW-40-10-40 treatment.

\subsection{Cadmium Concentration in Soybean Plants}

Cadmium concentration in seeds were significantly higher in GW-40-10-40 $\left(1.16 \pm 0.13 \mathrm{mg} \cdot \mathrm{kg}^{-1}\right)$ than other two treatments, $0.96 \pm 0.07 \mathrm{mg} \cdot \mathrm{kg}^{-1}$ and $0.8 \pm 0.12 \mathrm{mg} \cdot \mathrm{kg}^{-1}$ in GW-10 and GW-40 treatments, respectively (Figure 6). This can be explained with the relationship of Cd solubility and redox potential. The proportion of soluble Cd decreased abruptly with the decrease of soil redox potential [12]. In our experiment, the redox condition of the soil layer from 10 to $40 \mathrm{~cm}$ depth was oxidation in GW-40, reduction in GW-10 and reproductive stage, in which soybean needs a lot of water, in GW-40-10-40. Metal solubility increased as redox potential decreased [13]. However, opposite results has also been reported in our first experiment in 2012 [14]. From this two different types of data observed in two consecutive years, we can say that only redox potential is not only important factor but also $\mathrm{pH}$ of soil layer have the affect for heavy metal uptake in plants [15]. Among all parameters that might affect transport of heavy metals in soil systems, redox potential is also an important parameter, although $\mathrm{pH}$ is usually considered to be a prime importance [13]. As for stem Cd concentration, GW-40 treatment had significantly higher Cd than GW-10 and GW-40-10-40 treatment (Figure 7). Stem Cd concentration was (1.7 \pm $\left.0.2 \mathrm{mg} \cdot \mathrm{kg}^{-1}\right),\left(1.3 \pm 0.13 \mathrm{mg} \cdot \mathrm{kg}^{-1}\right)$ and $\left(0.96 \pm 0.07 \mathrm{mg} \cdot \mathrm{kg}^{-1}\right)$ in GW-40, GW40-10-40 cm and GW-40 treatment, respectively. As for root Cd concentration, there was no significant difference in those three treatments (Figure 8). $\mathrm{Cd}$ concentration in the soybean plants was different among three treatments due to difference of oxidation and reduction condition of soil layer. Previous research showed that accumulation of Cd was significantly reduced with diminishing Eh in reductive conditions formed by flooding rice fields [16]. Another researches showed that in soil reduction condition, the presence of sulphate $\left(\mathrm{SO}_{4}^{2-}\right)$ ion can be converted to sulfide ( $\left.\mathrm{S}^{2-}\right)$ ion which reacts with $\mathrm{Cd}$ and $\mathrm{Cu}$ and produces relatively insoluble Cadmium and Copper sulfide [17]. Concentration of Cd in soybean root was higher than the stem and seed. It might be because the intercellular spaces freely accessible to ions of root tissues were much greater than those of other parts. Some researchers also showed that accumulation of Cd in roots was higher than that in any other parts in plants [18] [19] which are similar to this study.

\subsection{Soybean Yield Components}

While the average main stem length of GW-40 (99.2 \pm 3.8$)$ was significantly higher than that of GW-10 (90.9 \pm 


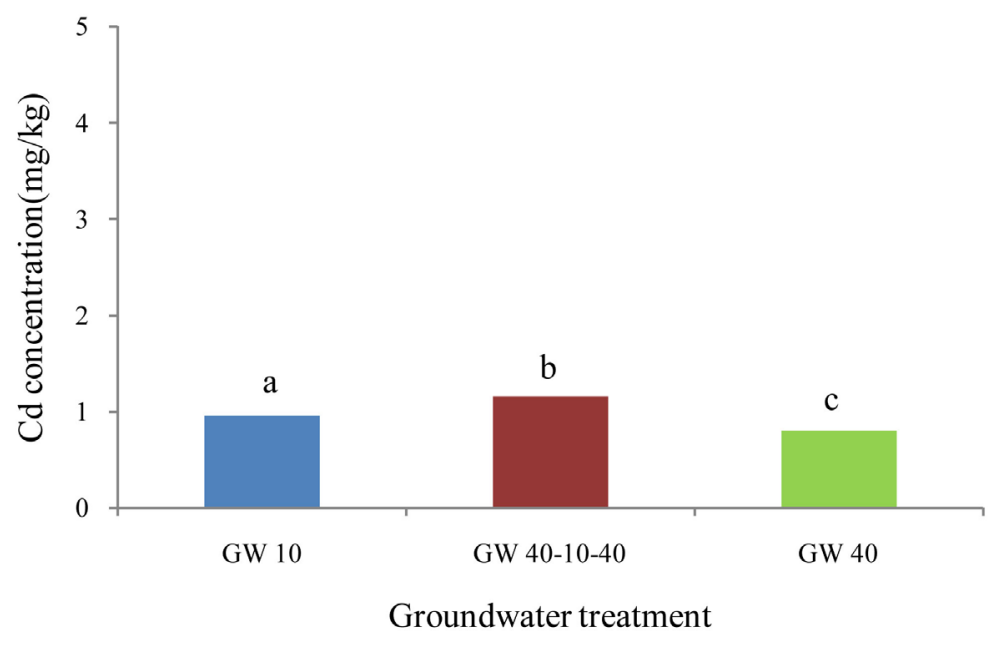

Figure 6. Seed Cd concentration of soybean (a, b and c indicate significant difference).

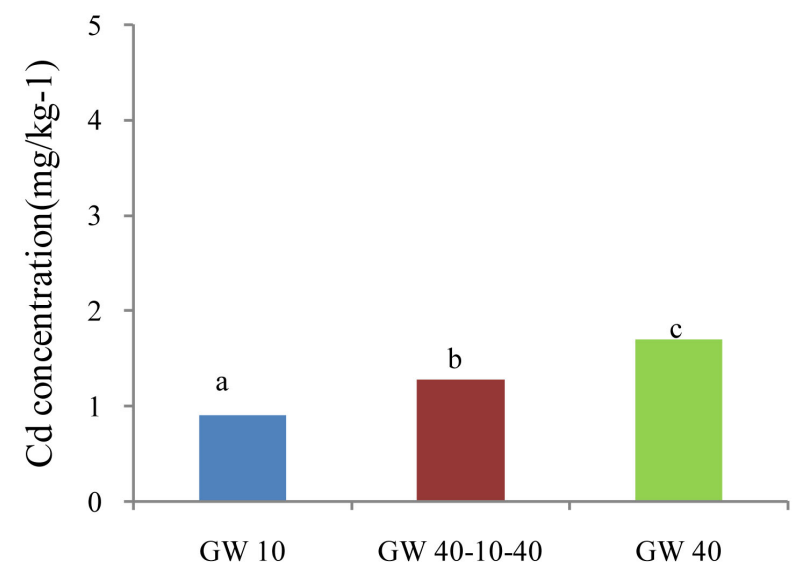

Groundwater level treatment

Figure 7. Stem Cd concentration.

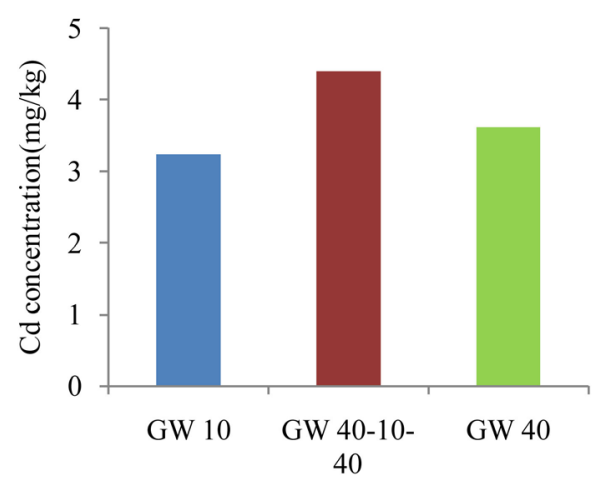

Groundwater level treatment

Figure 8. Root Cd concentration.

3.2) treatment (Table 2), that of GW-40 and GW-40-10-40 (95.9 \pm 4.3 ) was not significantly different. It means that the main stem length was higher in lower groundwater level than high groundwater level. Main stem length 
Table 2. Soybean yield components of three groundwater level treatments.

\begin{tabular}{ccccccc}
\hline Groundwater & \multicolumn{5}{c}{ Yield components } \\
Treatment & $\begin{array}{c}\text { Stem length } \\
(\mathrm{cm})^{*}\end{array}$ & $\begin{array}{c}\text { Stem diameter } \\
(\mathrm{mm})\end{array}$ & Branch No. & Seed/pod ${ }^{*}$ & $\begin{array}{c}100 \text { seed wt 15\% } \\
\text { moisture (g) }\end{array}$ & $\begin{array}{c}\text { Good seed } \\
\text { weight (g) }\end{array}$ \\
\hline GW-10 & ${ }^{\mathrm{a}} 90.9 \pm 3.2$ & $6.5 \pm 1.3$ & $7.0 \pm 0.8$ & ${ }^{\mathrm{a}} 2.0 \pm 0.7$ & ${ }^{\mathrm{a}} 33.3 \pm 2.9$ & $53.1 \pm 11.5$ \\
GW-40-10-40 & ${ }^{\mathrm{b}} 95.9 \pm 4.3$ & $7.5 \pm 0.7$ & $7.0 \pm 1.1$ & ${ }^{\mathrm{a}} 1.9 \pm 0.6$ & ${ }^{\mathrm{b}} 41.4 \pm 5.9$ & $47.4 \pm 9.5$ \\
GW-40 & ${ }^{\mathrm{b}} 99.2 \pm 3.8$ & $7.4 \pm 1.2$ & $7.1 \pm 1.2$ & ${ }^{\mathrm{b}} 1.9 \pm 0.2$ & ${ }^{\mathrm{b}} 40.4 \pm 2.7$ & $60.0 \pm 13.1$ \\
\hline
\end{tabular}

Note: Tukey test was performed at $5 \%$ level; letters indicates significant difference ( $\mathrm{n}=8$ for GW-10 cm \& GW-40-10-40 cm; $n=7$ for GW-40 cm after \pm value is standard deviation value).

was higher with lower water table treatments within three groundwater $(15 \mathrm{~cm}, 40 \mathrm{~cm}$ and $70 \mathrm{~cm})$ treatments [20]. Branch number and good seed weight was also measured the highest in GW-40 treatment among three treatments. Vegetative growth was inhibited following shorter stem [21] by the effect of excess moisture which is supported to the present study. No significant difference was among stem diameter, branch number, and total good seed weight in these 3 treatments.

100 seed weight of GW-40-10-40 treatment was significantly higher than that of GW-10 and it tended to be higher than that of GW-40 (Table 2). We got the higher yield in GW-40 treatment than in GW-10 and GW-40-10-40 treatments, and the lowest was in GW-40-10-40 or changing groundwater level. Effects of groundwater level on soybean yield have been reported by many researchers. Previous researches found 100 seed weight decreases for excess moisture in the soil at the ripening stage [22]. The optimum groundwater table depth for getting high yield differs from researcher to researcher; that is $20 \mathrm{~cm}$ [23], $40 \mathrm{~cm}$ [24] [25], $30 \mathrm{~cm}$ to $50 \mathrm{~cm}$ [26] and $50 \mathrm{~cm}$ [27]. Another research showed that, $10 \mathrm{~cm}$ groundwater level gave high soybean yield in the saturated soil culture at semi-arid tropical region in Australia [28]. In Japan most of the high yielded records were obtained on a drained paddy field where the water table maintained at around $50 \mathrm{~cm}$ depth from the soil surface. A stable groundwater level is important for obtaining higher yield of soybean and fluctuation of groundwater level reduced the yield [29] [30]. This phenomenon was also observed in our research.

\subsection{SPAD (Soil Plant Analyzer Development)}

The SPAD meter (KONICA MINOLTA SPAD-502) provides a simple, quick, portable and non-destructive method for estimating leaf SPAD value from which leaf chlorophyll content can be known by calculation. In SPAD value (Figure 9), we can clearly see the effect of groundwater level on SPAD value. In GW-10 treatment, vegetative stage (up to 50 days after sowing) the leaf chlorophyll content was lower (about 31) than that in GW-40 and GW-40-10-40 treatment (about 46) due to excess soil moisture. However, after 50 days it recovers as high as that of the other two treatments. We know the soybean plant has adaptation ability in high range of groundwater level. In previous study [28] reported that temporary chlorosis occurred when saturated-soil-water culture was given to soybean plants and that caused a reduction of leaf nitrogen content [31]. Reference [20] showed that chlorophyll contents decrease as well as seed yield decrease when groundwater level was high (15 $\mathrm{cm})$ compared to lower groundwater level $(40 \mathrm{~cm}$ and $70 \mathrm{~cm})$.

\subsection{Root Distribution}

While, over $90 \%$ of the total root weight was observed from the surface to $10 \mathrm{~cm}$ depth in GW-10 and GW40-10-40 treatments, some roots penetrated into $40 \mathrm{~cm}$ from the surface in GW-40 (Figure 10). There were two peaks of root distribution in the soil profile; the soil surface and a little above the water table [32] [33] which was similar to this experiment. Different root structure was also observed different among the three treatments; primary root system in GW-40 and secondary root (mat like structure) system in GW-10 and GW-40-10-40 treatment.

\section{Conclusion}

Accumulation of Cd by soybean plant was significantly affected by redox condition of soil layer which can be controlled by groundwater level. Among all parameters, which affect Cd uptake in soybean plants, redox potential should be one of the crucial things. A stable groundwater level is important for obtaining higher yield and 


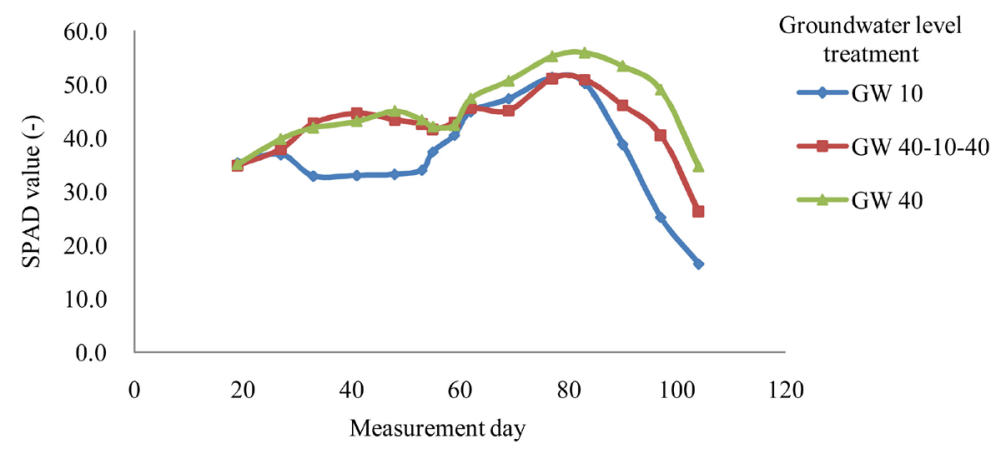

Figure 9. SPAD value of three groundwater level treatments.

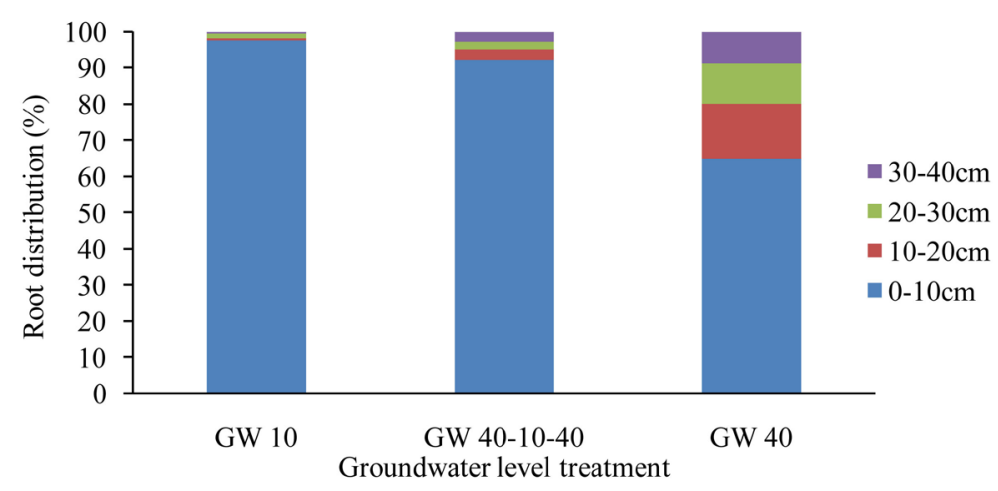

Figure 10. Root distribution of three groundwater level treatments.

groundwater fluctuation can reduce the yield. This can help in agronomic management in crop cultivation for minimization of $\mathrm{Cd}$ and other toxic metals uptake from polluted soils; it can also improve the management of polluted soil especially in developing countries since groundwater level management is relatively easy and does not cost so much. We need more research about groundwater level with other factors in Cd uptake in soybean (especially reproductive stage) and other crops with different Cd concentrations of soil.

\section{References}

[1] Auburn, A.L. (2000) Urban Technical Note No. 3. Soil Quality Institute.

[2] Bahadir, T., Bakan, G., Altas, L. and Buyukgungor, H. (2007). The Investigation of Lead Removal by Biosorption: an Application at Storage Battery Industry Wastewater. Enzyme and Microbial Technology, 41, 98-102. http://dx.doi.org/10.1016/j.enzmictec.2006.12.007

[3] Kobayashi, J. (1978) Pollution by Cadmium and the Itai-Itai Disease in Japan. In: Oehme, F.W., Ed., Toxicity of Heavy Metals in the Environment, Part 1, Marcel Dekker, New York, 47-158.

[4] Sommers, L.E. and Lindsay, W.L. (1974) Effect of pH and Redox on Predicted Heavy Metal-Chelate Equilibria in Soils. Soil Science Society of America Journal, 43, 39. http://dx.doi.org/10.2136/sssaj1979.03615995004300010007x

[5] Masscheleyn, P.H., Delaune, R.D. and Patrick Jr., W.H. (1991) Arsenic and Selenium Chemistry as Affected by Sediment Redox Potential and pH. Journal of Environmental Quality, 20, 522. http://dx.doi.org/10.2134/jeq1991.00472425002000030004x

[6] Wright, J.A., Shirmohammai, A., Magette, W.L., Fous, J.L., Bentson, R.L. and Parsons, J.E. (1992) Water Table Management Practice Effects on Water Quality. Transactions of the ASAE, 35, 823-831. http://dx.doi.org/10.13031/2013.28667

[7] Kalita, P.K. and Kanwar, R.S. (1993) Effect of Water Table Management Practices on the Transport of Nitrate-N to Shallow Groundwater. Transactions of the ASAE, 36, 413-421. http://dx.doi.org/10.13031/2013.28353

[8] Asami, T. (2010) Toxic Metal Contamination in Japan. Hirakawa Kogyosha Ltd., Japan, 233. (In Japanese)

[9] Ministry of Agriculture, Forestry, and Fisheries of Japan (MAFF) (2002) Investigation of Cd Concentration of Staple Crops: The Outline of the Results. MAFF, Tokyo. 
[10] National Institute of Agricultural Science and Technology (ICAR) (1988) Methods of Soil Chemical Analysis. http://www.icar.org.in/files/ICAR-ITP/iiss.pdf

[11] Ministry of Agriculture, Forestry and Fisheries of Japan (MAFF) (1979) The Foundation of Environmental Paddy Field and Investigation of Paddy Field, Water Quality and Crop Analysis Method. National Conference of Paddy Field Preservation, Tokyo, 113-115.

[12] Iimura, K. (1981) Metal Stress in Rice Plants. Japan Scientific Societies Press, Tokyo, 19.

[13] Chuan, M.C., Shu, G.Y. and Liu, J.C. (1996) Solubility of Heavy Metals in a Contaminated Soil: Effects of Redox Potential and pH. Water, Air, and Soil Pollution, 90, 543-556. http://dx.doi.org/10.1007/BF00282668

[14] Haque, M.Z., Sasaki, C., Matsuyama, N., Annaka, T. and Sasaki, K. (2014) Effect of Groundwater Level on Cadmium Uptake and Yield of Soybean from Cadmium Polluted Soils. International Journal of Engineering Research and Development, 5, in Press.

[15] Street, J.J., Sabey, B.R. and Lindsay, W.L. (1978) Influence of pH, Phosphorus, Cadmium, Sewage Sludge and Incubation Time on the Solubility and Plant Uptake of Cadmium. Journal of Environmental Quality, 7, 286-290. http://dx.doi.org/10.2134/jeq1978.00472425000700020027x

[16] Lu, R.K., Xiong, L.M. and Shi, Z.Y. (1992) Cadmium Contents of Rock Phosphates and Phosphate Fertilizer of China and Their Effects on Ecological Environment. Acta Pedologica Sinica, 29, 150-157.

[17] Ono, K., Gamo, M. and Nakanishi, J. (2003) Factors Affecting Cadmium Concentration in Rice in Japanese Paddy Fields. Proceedings of 24th Annual Meeting: North America, 71.

[18] Jarvis, S.C., Jones, L.H. and Hopper, M.J. (1976) Cadmium Uptake from Solutions by Plants and Its Transport from Roots to Shoots. Plant and Soil, 44, 179-191. http://dx.doi.org/10.1007/BF00016965

[19] Cui, Y., Zhang, X. and Zhu, Y. (2008) Does Copper Reduce Cadmium Uptake by Different Rice Genotypes? Journal of Environmental Sciences, 20, 332-338. http://dx.doi.org/10.1016/S1001-0742(08)60052-2

[20] Shimada, S., Kokubun, M. and Matsui, M. (1995) Effect of Water Table on Leaf Chlorophyll Content, Root Growth and Yield. Japanese Journal of Crop Science, 64, 294-303. http://dx.doi.org/10.1626/jcs.64.294

[21] Garside, A.L., Lawn, R.J. and Byth, D.E. (1992) Irrigation Management of Soybean (Glycine max (L.) Merril) in a Semi-Arid Tropical Environment. Effect of Irrigation Frequency on Growth, Development and Yield. Australian Journal of Agricultural Research, 43, 1003-1017. http://dx.doi.org/10.1071/AR9921003

[22] Sugimoto, H., Koesmaryono, Y. and Nakano, R. (2000) Effects of Excess Moisture in the Soil at Different Stages of Development on the Growth and Seed Yield of Soybean. Pakistan Journal of Biological Sciences, 3, 1465-1467. http://dx.doi.org/10.3923/pjbs.2000.1465.1467

[23] Abe, C., Huruno, S. and Uchida, H. (1981) Studies on Effective Water Management for Paddy Soil of Volcanic Ash. (III) Growth and Yield of Crops on the Fields Converted from the Paddy Ones at Different Levels of Underground Water. Bulletin of the Tochigi Agricultural Experiment Station, 27, 29-40. (In Japanese)

[24] Miyagawa, T. and Ishimaru, H. (1975) Studies on Soybean Crop Grown in Temporary Paddy Field. 2. The Relationship between Soil Moisture and Ecological Reaction of Autumn Soybean Crop. Report of the Kyushu Branch of the Crop Science Society of Japan, 42, 40-41. (In Japanese)

[25] Ishibashi, Y. Jinno, H. and Tsuruuchi, T. (1982) Influence of Groundwater Level on Growth and Yield of Upland Crops in Temporary Paddy Field. Report of the Kyushu Branch of the Crop Science Society of Japan, 49, 60-65. (In Japanese)

[26] Ueno, Y. (1979) Effect of Irrigation and Groundwater Table Depth on Growth and Yield of Soybean. Kinki Chugoku Agricultural Research, 58, 42-46. (In Japanese)

[27] Shibata, M. and Endo, T. (1976) Growth and Yield of Soybeans Grown at Different Water Table Levels on Drained Paddy Fields. Tohoku Agricultural Research, 18, 104-107. (In Japanese)

[28] Garside, A.L., Lawn, R.J. and Byth, D.E. (1992) Irrigation Management of Soybean in a Semi-Arid Tropical Environment. Response to Saturated Soil Culture. Australian Journal of Agricultural Research, 43, 1033-1049. http://dx.doi.org/10.1071/AR9921033

[29] Fukui, J. (1965) Physiological and Ecological Studies of Soybean in Relation to Soil Moisture Condition. Journal of the Central Agricultural Experiment Station, 9, 1-68. (In Japanese)

[30] Seko, H., Samura, T., Kagotani, H., Futami, K., Yoshikura, J., Swada, T. and Aoyama, Y. (1997) Stable High Yield Cultivation of Soybean in under Drained Rotational Upland Field. Effects of Underground Water Level and Watering on Growth and Yield of Soybean. Bulletin of the Hoyogo Prefectural Agricultural Center for Experiment Extension and Education, 35, 21-24. (In Japanese)

[31] Sugimoto, H., Amemiya, A., Satou, T. and Takenouchi, A. (1988) Excess Moisture Injury of Soybeans Cultivated in an Upland Field Converted from Paddy. Effects of Excessive Soil Moisture on Bleeding, Stomatal Aperture and Mineral 
Absorption. Japanese Journal of Crop Science, 57, 77-82. (In Japanese) http://dx.doi.org/10.1626/jcs.57.77

[32] Reicosky, D.C., Millington, R.J., Klute A. and Peters, D.B. (1972) Patterns of Water Uptake and Root Distribution to Soybeans (Glycine max.) in the Presence of a Water Table. Agronomy Journal, 64, 292-297. http://dx.doi.org/10.2134/agronj1972.00021962006400030011x

[33] Tanaka, N., Mihara, M., Arima, S. and Harada, J. (1994) Applicable Range of the Pipe Model to the Structure of Soybean (Glycine max Merr.) Root System. Japanese Journal of Crop Science, 63, 63-67. (In Japanese) http://dx.doi.org/10.1626/jcs.63.63 
Scientific Research Publishing (SCIRP) is one of the largest Open Access journal publishers. It is currently publishing more than 200 open access, online, peer-reviewed journals covering a wide range of academic disciplines. SCIRP serves the worldwide academic communities and contributes to the progress and application of science with its publication.

Other selected journals from SCIRP are listed as below. Submit your manuscript to us via either submit@scirp.org or Online Submission Portal.
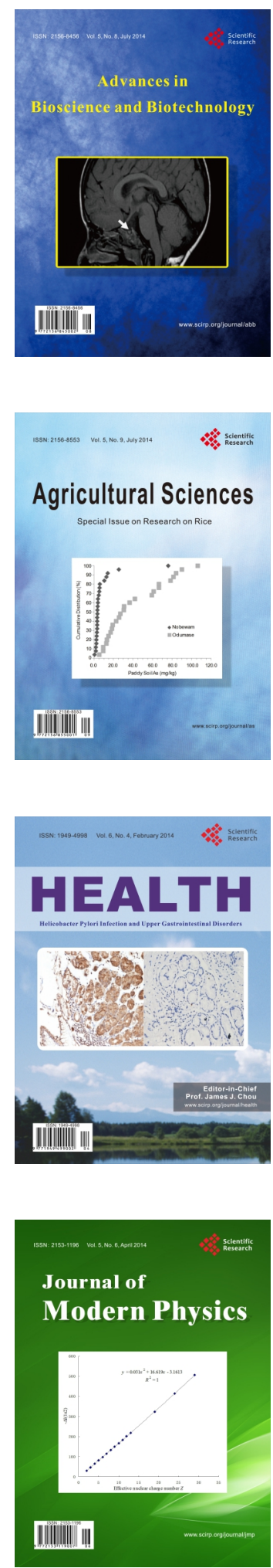
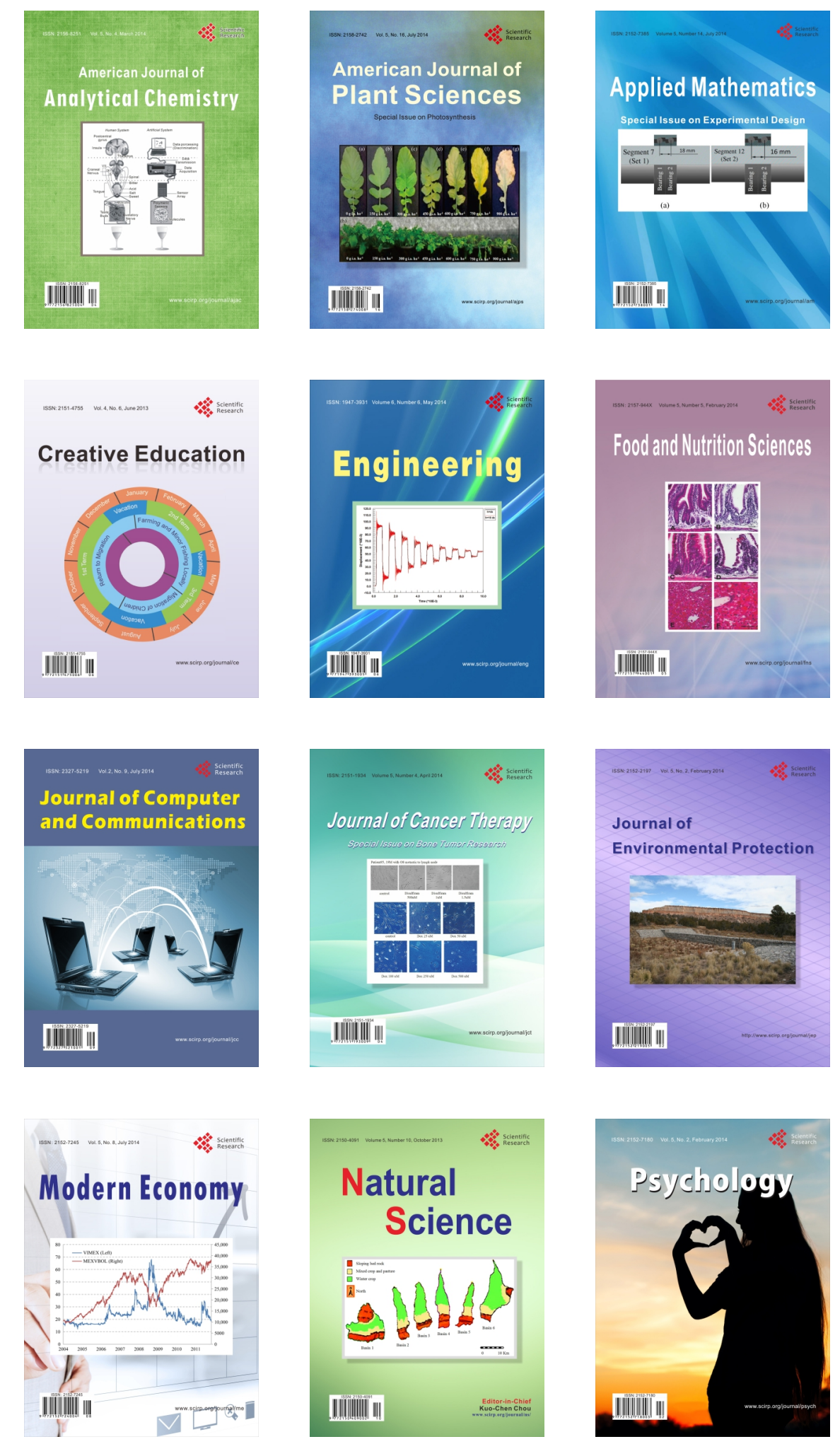